\title{
Implementing a land value tax: considerations on moving from theory to practice
}

Article

Accepted Version

Creative Commons: Attribution-Noncommercial-No Derivative Works 4.0

Hughes, C., Sayce, S., Shepherd, E. and Wyatt, P. (2020) Implementing a land value tax: considerations on moving from theory to practice. Land Use Policy, 94. 104494. ISSN 02648377 doi: https://doi.org/10.1016/j.landusepol.2020.104494 Available at https://centaur.reading.ac.uk/88754/

It is advisable to refer to the publisher's version if you intend to cite from the work. See Guidance on citing.

To link to this article DOI: http://dx.doi.org/10.1016/j.landusepol.2020.104494

Publisher: Elsevier

All outputs in CentAUR are protected by Intellectual Property Rights law, including copyright law. Copyright and IPR is retained by the creators or other copyright holders. Terms and conditions for use of this material are defined in the End User Agreement.

www.reading.ac.uk/centaur

\section{CentAUR}


Central Archive at the University of Reading

Reading's research outputs online 


\title{
Implementing a land value tax: considerations on moving from theory to practice
}

\author{
Cathy Hughes \\ Sarah Sayce \\ Edward Shepherd \\ Peter Wyatt
}

\begin{abstract}
A land value tax is a recurrent tax on landowners based on the value of unimproved land. There is a widely held view that a land value tax is an economically efficient means of taxing wealth and of encouraging land development. The arguments presented in the policy and academic literature tend to concentrate on the compelling theoretical case, but most do not consider the detail of how such a tax might be implemented. Indeed, land value taxation is not widely implemented as a standalone real estate tax despite the strong theoretical rationale for its use. We explore why this might be by identifying key practical, political and economic factors surrounding the implementation and operation of land value taxation in six countries. We examine the various rationales for the introduction of land value tax, reasons for its continued use or abolition (where applicable) as well the particular practical and political issues which policymakers need to consider prior to introducing land value taxation. These include the need for a comprehensive up-to-date land registry and forward planning of land use at plot level; the provision of a well-resourced and informed valuation profession; resources to undertake robust valuations which separate the value of land from the value of improvements for developed plots and do so on the basis of highest and best use; and the need for widespread political support for the introduction of a new tax (which may be difficult to secure). These issues present significant uncertainty in comparison with already-existing forms of land and property taxation. We conclude that these issues may therefore provide some explanation as to the lack of widespread adoption of land value tax despite the economic theoretical arguments in its favour.
\end{abstract}

Keywords: land value taxation; land reform; tax design; unimproved land value. 


\section{Introduction}

A land value tax is a recurrent tax on landowners based on the value of 'unimproved' land ${ }^{1}$. It is normally levied on the capital value of land, but could, in theory, be levied on rental value. There is a strong and widely held view that land value tax is an economically efficient and beneficial form of taxation (Mirrlees et al., 2011; Corlett et al., 2018). This is because economic theory suggests that such a tax provides a broad, stable and identifiable tax base that is correlated with wealth; is not distortive of behaviour; is a just form of taxation of the 'unearned increment' in the value of land; and may promote the development of under-utilised land. This last point means the tax must be based on land values that assume 'highest and best use' (HABU) rather than existing use. This is important in countries where there is a political desire to encourage optimum use of land.

Yet, despite these seemingly compelling economic arguments, land value taxation (LVT) is not widely implemented. According to Almy (2016), of 167 countries he examined, only seven had implemented a tax on land as distinct from a combined tax on land and improvements to the land, such as buildings. Indeed, in countries where LVT has been introduced, it tends to be only one of several land and property taxes and raises a small proportion of overall tax revenue (Hughes et al., 2018). Whilst LVT continues to be levied in some countries (for example Denmark, Estonia and parts of Australia and the United States) in other countries long associated with LVT, such as South Africa, it has been all but phased out in favour of alternative means of raising government revenue. The question therefore arises: why has LVT not been more widely adopted given the strong theoretical rationale for its use by governments in order to tax wealth and encourage land development?

We attempt to answer this question by identifying key political and technical factors surrounding the implementation and operation of LVT and, through so doing, we suggest possible explanations as to the low uptake of LVT worldwide. The paper begins with a discussion of the theoretical case for LVT and situates it within a range of approaches to land and property taxation. We then review the operation of LVT in six countries where land value tax has been implemented in order to explore the rationales for

\footnotetext{
${ }^{1}$ By the value of 'unimproved' land, we mean the value of land not taking in to account any structures on the land, or any other improvements such as crops, landscaping, infrastructure etc. It does not mean that it is a tax only on land that is 'bare' of buildings or infrastructure. However, actually-existing instances of land value taxation can incorporate definitions of 'unimproved' land which may include some types of improvements e.g. the definition of 'site value' in Queensland Australia includes improvements to the physical nature of the land to prepare it for development, but excludes other types of improvements such as buildings.
} 
the introduction of land value tax, reasons for its continued use or abolition (where applicable) as well as how practical questions relating to tax design and administration have been addressed. This is followed by a discussion of the practical and political issues which policymakers would need to consider prior to introducing a land value tax. We conclude that these may provide some explanation as to the lack of widespread adoption of land value tax despite the economic theoretical arguments in its favour.

\section{Land and property taxation in theory}

Generally, land and property taxes are levied to raise money for services provided at a local level, for general taxation or to achieve wealth re-distribution; they can be classified as either recurrent (usually annual) or event-based. A recurrent tax provides regular and predictable revenue and the rate can be low if the tax base encompasses a wide range of land uses, owners and users. It is usually assessed with reference to value (market capital value, market rental value or cadastral value based on parameters such as land use, location or size) of either unimproved or improved land (e.g. including buildings on the land). Event-based taxes include transfer taxes and wealth taxes on, say, capital gains or inheritance. Many countries, especially those with developed, or rapidly developing, urban areas also levy betterment taxes or use land value capture instruments which are event-based. These are levied on any increase in the value of land attributable to actions of, or investment by, the state, such as grant of consent for development or the provision of infrastructure. In this paper the focus is on LVT, the recurrent taxation of unimproved land, which can be used to recurrently tax wealth held in land so obviating the need for an event-based tax.

The theoretical case for LVT is strong. Classical and neo-classical economists such as Adam Smith, David Ricardo, John Stuart Mill and Alfred Marshall demonstrated that the economic rent (and its capitalised equivalent, capital or market value) which land is able to earn over and above the return generated after optimally employing labour and capital is determined by its scarcity and its location, neither of which are derived from any productive activity on the part of the landowner. Land value is, therefore, the price of monopoly: the scarcer and less substitutable a parcel of land is, and the more attractive the location in relation to the market (consumers) and factors of production (labour, raw materials), the more valuable the land. 
In countries where property rights are held privately, the combination of private property rights and monopoly land value creates two political issues: unearned accumulation of land value (or wealth) and unequal distribution of that wealth. One means of recovering unearned land value is a tax. Adam Smith argued that a tax on unimproved land value would not harm economic activity and would not increase land rents (Smith, 1776). The idea of a recurrent tax on unimproved land value has been propounded ever since, with 19th century liberal economist Henry George making the most well-known case for a single tax on unimproved land value (George, [1881], 2011). Yet George's proposed single tax on unimproved land to replace all other taxes has never been introduced. Instead countries have introduced land taxes which sit alongside other forms of taxation, usually at low rates and capturing only a tiny fraction of land value, or else they tax improved land, rather than unimproved land. These forms of LVT are, therefore, a small vestige of George's original idea.

In addition to its economic efficiency, LVT is believed to potentially offer a range of other benefits. Youngman (2016) shows that there is a great deal of insightful research and expert analysis demonstrating the potential for land-based taxes to make a positive contribution to local government revenue, decentralization efforts, and land policy initiatives. Potential benefits deriving from LVT identified in the academic and policy literature include:

- since it is a tax on unimproved land, it should not distort choices about investment in improvements (Dye and England, 2010);

- assuming it is levied on the 'highest and best use' (HABU) of the land, rather than the existing use, it may encourage optimum use of land (Commission on Local Tax Reform, 2015) and promote reuse of land that may be unused, derelict or vacant (assuming such land is taxable) (Lyons, 2005);

- it can capture betterment on a 'non-event' (i.e. recurrent) basis (IPPR, 2005; Mirrlees, 2011);

- assuming it is levied on the HABU of the land, rather than the existing use, by raising the holding cost of land, it may discourage land speculation and encourage development (Foldvary and Minola, 2017);

- it may encourage denser development and therefore limit urban sprawl (Connellan, 2004);

- it may encourage the break-up of property holdings where the holdings have resulted in sub-optimal use (Forster, 2000); and

- it may stabilise the price of real estate by reducing and stabilising underlying land prices (George, 1879). 
Underlying these arguments in favour of LVT is the perception that it will reduce wealth inequality through taxing wealth held in land. These theoretical rationales for the introduction of LVT in order to tax wealth and the 'unearned increment' are compelling. This paper does not set out to seek support for or test these claims (see Anderson (2009) for a review of the evidence). Rather, because of a continuing interest in LVT in different jurisdictions across the globe, it seeks to identify the key practical issues that would need to be considered by any government wishing to implement a form of LVT, and proposes courses of action that might address them.

\section{Land value tax in practice}

Given the objective outlined above, this section of the paper reviews the academic and policy literature relating to implementation of LVT in six countries: South Africa, Estonia, Australia (Queensland), Denmark, New Zealand and Namibia. LVT is fully operational in Queensland, Denmark, Namibia and Estonia, but was abolished in South Africa through the provisions of the Local Government: Municipal Property Rates Act 6 of 2004 and only exists in reduced form in New Zealand after a long period of country-wide adoption. These countries provide contrasting experiences of LVT in terms of the rationale for its introduction, its governance and administration, the extent of the tax base, the basis on which land is valued for LVT and the relationship between land value tax and other property taxes. Whilst they do not provide a complete coverage of countries with an LVT, collectively they provide an insight into the issues associated with LVT in practice.

\section{$\underline{\text { Rationales for the introduction and continued use of LVT }}$}

LVT was introduced in the six countries to meet a range of political and economic needs. These needs are related to the histories and political economies of the countries in question. For example, the land value tax in Denmark, introduced in 1902 and known as Grundskyld, owes its form and origins to the introduction of Georgist thinking at the beginning of the 20th century (Vickers, 2009). Lefmann and Larsen (2000, p.185) claim that Denmark was "the first country in the world that had a political party of national influence whose chief aim was to make land value the principal and, if possible, the only source of tax revenue in the country". Although LVT had the backing of all major political parties throughout the 20th century based on economic grounds and social propensity, it had fallen back in terms of ambition by the beginning of the 21st century as a result of a tax shift towards land and property usage 
rather than ownership. However, land value tax, based on highest and best use and levied on the owner, still remains an integral part of the tax base.

In Estonia and Namibia national LVT was introduced in the context of political and economic restructuring in the aftermath of the achievement of independence from foreign administration. In the Estonian case, it was hoped that the introduction of a land value tax in 1993 would stimulate more productive use of previously state-owned land which had been restored to private ownership after independence from Soviet authority in 1991 and so as to provide a source of much-needed tax revenue (Malme and Tiits, 2001). In Namibia a land value tax on commercial farmland was introduced in 2004 as part of the post-independence land reform agenda given the preponderance of white-ownership of agricultural land. The tax rate was designed to discourage ownership of multiple farms with the tax rate increasing as the number of properties owned increased (United Nations, 2011). The Namibian government was perceived to handle the issue with sensitivity; for example the tax was only introduced after extensive consultation with key stakeholders including white farmers, which succeeded in securing their general agreement. Because of this process, the introduction of the land tax in Namibia has been described as a success (Franzsen and McCluskey, 2017, p.322).

Interestingly, one of the original rationales for the introduction of LVT in Australia and New Zealand was also to address the inequalities of concentrations of wealth in very large estates. A federal land value tax was introduced in Australia in 1910 with the specific objective of breaking up the ownership of large estates and large tracts of under-utilised land and of raising revenue to finance a nationwide old-age pension plan (Forster, 2000; Smith, 2005). However, the owners of large estates often escaped the tax by nominally subdividing the land among family relations (Forster, 2000) and the federal land tax was abolished in 1952 because it was not achieving the objective of breaking up large estates and had high administrative costs (Franszen, 2009). In the meantime, the Australian states had introduced their own land taxes, the last of which was Queensland, which introduced its state land tax in 1915 (Forster, 2000). Today, land tax in Australia is primarily targeted at raising revenue (rather than at intervening in the structure of land ownership).

In the New Zealand case, influenced by Georgist thinking, the government introduced a national land tax (NZLT) in 1878, believing that wealthy landowners had greater taxable ability but low tax burden compared to the working classes who were generating the bulk of government revenue through tariffs 
(Gupta, 2016). A year later, when land values began to fall and landowners argued that it was unfair to tax a group who received no special benefits, the NZLT was repealed in favour of a tax based on capital (improved) values, but it was later reinstated in 1894. However, by 1910 the tax raised only $10 \%$ of government revenue and by 1967 the figure was 0.5\% (Barrett and Veal, 2012). In 1967 a taxation review committee report noted that the tax was no longer effective as a means of breaking up large land holdings and recommended its abolition, although this was not acted upon at that time. By 1982 only $5 \%$ of total land value was taxed and the nationwide NZLT was thought to be duplicating local authority general rate levies (Bush, 2003). The NZLT was abolished in 1992 and, since that time, land tax only exists at the local government level in New Zealand.

Like Namibia and Estonia, the South African experience with LVT can also be seen in the context of colonialism and radical political and economic change. However, whereas in Namibia and Estonia national LVT was introduced in the aftermath of such change, in the South African case the end of apartheid and the establishment of the democratic government of the African National Congress (ANC) in 1994 precipitated the end of LVT in South Africa after many years of operation. Prior to this, municipalities had the option of selecting one of three property rating systems, one of which was the 'site-rating' system which taxed land excluding improvements. The post-1994 political and institutional context in South Africa prompted a review of the various former property tax systems (Franzsen and McCluskey, 2000; McCluskey and Franzsen, 2004). As part of this it was decided to abolish the three rating options and to introduce a single uniform system of property tax for the whole country levied on the market value of land and buildings; therefore there is no longer LVT in South Africa.

The six cases examined for this paper suggest that there is a range of reasons for the introduction of LVT, its continued use and (in some cases) its eventual abolition. In cases where LVT was introduced initially with the objective of adjusting the distribution of land ownership, this objective was not fully achieved and the tax was either eventually dropped or came to be mainly aimed at revenue generation rather than behavioural change (e.g. Australia and New Zealand), although Namibia seems to have enjoyed some success in raising revenue from its national land value tax which can be spent on land reform initiatives administered through the government's Land Acquisition and Development Fund (United Nations, 2011). 


\section{Governance and administration of LVT}

The governance and administration of LVT in the six countries is clearly influenced by size and government structure. For example, in Queensland Australia there are two tiers of LVT - one at state (i.e. sub-federal) level and one at local government level (i.e. council property rates). This is also the case in Namibia where there is a national land tax on commercial farmland as well as locally-set property rates which can be levied on a range of bases including on the value of the land without improvements (Franzsen \& McClusky, 2017, p.322), whereas in Estonia there is a single land value tax administered at national level although the revenue is distributed to local municipalities. In South Africa, prior to the abolition of LVT after 2004, the tax was set and collected at municipality (rather than provincial or national) level. Similarly, in New Zealand, following the abolition of the national land tax, territorial local governments have the option of levying a property tax assessed on a number of bases, including on the basis of unimproved land value.

The level at which land value tax is administered, collected and spent and the basis on which it is levied appears to be a function of the purpose of such a tax. A land tax that is used to pay for services tends to be locally administered whereas a tax on wealth tends to be centrally administered. The latter has a redistributive function with the relationship between the tax revenue and the tax expenditure being less clear than in the case of a service tax. This can potentially reduce transparency and public understanding. For example in Queensland, Australia there exists both a local land value tax (i.e. property rates), used to for services and infrastructure and a state land tax also used to pay for government services and infrastructure. This, according to Mangioni (2016, p. 309) can cause confusion as "these taxes are presented as two different taxes" whereas in fact "state land tax and local government rates are the one generic, recurrent tax spread across two tiers of government in Australia."

\section{The tax base and rates}

Land value tax is normally designed to be levied on the owners of land, although exemptions are widespread. For example, exemptions from state land tax in Queensland Australia include land used solely for agriculture and land used as a home (although homes are not exempt from municipal property rates, i.e. local land value tax). Exemptions from LVT in Estonia include nature reserves, land under churches, public water bodies and land adjacent to buildings of diplomatic missions. This is in 
accordance with Brown and Hepworth's (2002) claim that main exemptions from the payment of land value tax tend to be in respect of state-owned land and land on which religious, historic or community buildings are located. However, in Denmark land tax is charged on all land, including agricultural property and assets owned by central or local government, albeit with some exemptions and reliefs including for churches, royal residencies, schools and hospitals (Muller, 2005).

A uniform tax rate is simple and, on the face of it, equitable. However, differential tax rates are common. In Queensland Australia for example, local councils are able to choose between levying a uniform general rate or a differential general rate (based on land use, access or consumption of council services). In Estonia, land is zoned by use and local councils decide the tax rates to be applied to each zone on an annual basis. In the Danish case, agricultural, forestry land and public buildings are liable for a reduced rate of land tax. There are also a range of threshold values for land value tax. In Queensland Australia, for example, state land tax is targeted at more wealthy landowners being payable only when land value exceeds a relatively high threshold; in Namibia, as stated above, the tax rate on agricultural land increases with the number of properties owned.

\section{Valuation}

Basing LVT on the unimproved value of land brings with it various technical valuation challenges which are addressed in different ways in the countries analysed for this paper. In Estonia, when the tax was first introduced, the country had neither the legal framework nor the land and price information necessary for market valuation (Malme and Tiits, 2001). Nonetheless, they estimated urban land values by judging location, quality and use attributes, and rural land values based on soil productivity (Malme and Tiits 2001). Now, as reliable price information has become available through the National Transactions Register, the valuations have been increasingly based on market transaction data.

In Queensland Australia, valuations are ideally based on comparable land sales of 'vacant or lightly improved land', but where these are not available, improved land sales may be used as comparable evidence, adjusted so as to exclude the value of the improvements. An increasing lack of vacant land sales has prompted greater reliance on improved land sales (Mangioni, 2016), and this has led to a lack of transparency and inconsistency of approaches in the valuation of land and has raised concerns regarding the economic efficiency, simplicity and transparency of the land tax. Consequently LVT in 
Australia has "constantly been challenged and is one of the more disliked, visual and least understood taxes imposed by governments" (Mangioni, 2016, pp.73-74).

This echoes the South African experience. When the South African government was considering options prior to the introduction of the Local Government: Municipal Property Rates Act 6 of 2004, the South African Institute of Valuers, representing the valuation profession in South Africa, officially supported capital improved values (rather than unimproved values) as the preferred rating approach, citing lack of public understanding of a land value system, as well as the lack of vacant sales within urban areas as primary reasons (McCluskey and Franzsen, 2005). A survey of South African valuers conducted by McCluskey and Franzsen (2004) found support for the use of capital improved values because it enables the valuation roll to provide useful data on all improvements and other new developments; capital values provide a more buoyant revenue base than land only; and capital values can achieve a better distribution of the tax burden. In addition, it was argued that capital improved value reflected ability to pay rates more appropriately.

Ability to pay is a key issue for LVT. For landowners who are wealthy in terms of land assets, but do not generate an income from that land and therefore are not able to easily meet the annual costs of a tax liability, the introduction of a land value tax could meet resistance. The classic example of this is the asset-rich but cash-poor retiree. The prospect of increasing the tax liability of vulnerable older people who lack the ability to pay would not be welcomed by many politicians. Yet, taxing their wealth is an objective that many supporters see as valid (e.g. Intergenerational Commission (2018)), but is not without critics (Boadway and Pestieau, 2018). To overcome this, a land value tax may be designed so as to be payable by people over retirement age upon the sale of an asset or death, as is the case in Denmark.

The frequency with which valuations are carried out varies across the examples reviewed for this paper. In Estonia there is no fixed revaluation cycle - it is for the government to decide when a revaluation should be done whereas Danish land owners have their land revalued every two years. In Queensland Australia valuations are generally carried out annually in order to avoid large variations in valuation which can occur with more infrequent valuations, particularly in highly developed urban areas. However, according to McCluskey (2005), it is questionable whether frequent annual valuations are 
necessary in more rural areas with more stable land values, particularly when the cost of such frequent valuations is taken in to account.

\section{$\underline{\text { Relationship between LVT and other property taxes }}$}

Whereas Henry George advocated for LVT to be a single tax to replace all other taxes, the examples of LVT studied for this paper typically serve alongside other forms of land and property taxation, but to varying degrees. The exception is Estonia which doesn't have any other specific property taxes, although there is a small fee payable on the transfer of property. There, capital gains are taxed as part of income, with exemptions for primary residences. New Zealand has limited other property taxation with only a limited application of capital gains tax and no inheritance tax.

In Denmark, the Grundskyld land value tax exists alongside a Service Tax (Daekingsafgift) which is based on the value of commercial buildings only and a Property Value Tax (Ejendomsvaerdiskat) based on the capital value of owner-occupied dwellings and summerhouses (i.e. land and improvements). The Property Value Tax, according to Lindegaard (2018) "is regarded as an investment tax, to make sure that investment income on properties are not better than financial yields, which are taxed". These three taxes exist alongside property gains and transfer tax.

\section{Issues for consideration when implementing a land value tax}

The review of examples of LVT in the six countries studied for this paper suggest a number of important practical issues which would need to be carefully considered by any government considering the introduction of a form of LVT. The issues relate to establishment of the tax base, valuation of the taxable entities, and governance and administration. In this section of the paper, these issues are described and practical courses of action are suggested.

\section{The purpose of the tax}

A key question in this regard is whether the purpose of a new land value tax is to increase overall tax revenue or remain revenue neutral but with a change in who bears the burden. It is therefore important that the social or/and political purpose of the tax is clear and understood: is it a tax on wealth, 
a tool to promote development, or to pay for services? If a land value tax is introduced and presented as a tax which replaces some of the existing tax liabilities for landowners, then this may increase the degree of political acceptance.

The examples considered in Section 3 reveal that LVT usually operates alongside other land and property taxes, though to varying degrees. These might be taxes administered at different levels of government (state and municipality for example) and could include other recurrent land and property taxes, transaction taxes and inheritance taxes. The tax base and taxation rates of existing taxes may therefore need to be adjusted to accommodate changes introduced by a land value tax, or LVT might provide the opportunity to abolish some existing taxes in their entirety.

The issue of 'ability to pay', which was identified in Section 3, is largely a political one, but addressable through sensitive tax design, including consideration as to what rate the tax is set and the resultant liabilities in comparison with those under the present taxation regime, together with any reliefs, but bearing in mind that any relief system will place extra burden elsewhere.

In terms of public acceptability, it is likely to be important that LVT is not viewed as adding complexity or additional tax burden. A decision would have to be made as to whether to bring all land in to the tax base for a land value tax or to allow some exemptions and reliefs. However, if the tax liability on land which is currently exempt or subject to relief were to increase, this might meet political resistance. This is an issue with which most of the countries reviewed for this paper have grappled. To achieve optimal effectiveness, the scope of tax inclusion must be wide: but in reality, exemptions abound. In addition, the threshold value which triggers a tax liability for various types of property would need to be carefully considered, as well as whether it should be taxed at progressive rates or deferred. This would be important so as not to risk the viability of land intensive businesses.

These are, therefore, largely technical issues relating to tax design which do not in themselves necessarily present an impediment to the introduction of a land value tax. However, they do point towards the need for policy makers to be very clear about the purpose of a new land value tax would be (including deciding if it is primarily a wealth tax or a service tax), and to be aware of the potential political and economic risks associated therewith. 


\section{Development and LVT}

Economic theory suggests that a land value tax based on highest and best use (HABU) would encourage the development of vacant or under-developed land because of the increased holding cost, thereby creating an incentive to sell the land or develop it. However, this only works in cases where land can be viably developed. Where land is economically not viable to develop, it follows that there is no value on which to levy a land value tax. Such land may require subsidy rather than taxation (Hughes et al. 2018). In the six countries reviewed, there was no firm evidence that LVT was a consistently effective tool for bringing land forward for development. Instead of taxation, more direct forms of regulatory control such as land use planning, development control and infrastructure investment are likely to be more effective.

That said, land value tax could potentially be effective in cases where there is evidence of speculative land banking by owners or land promoters who have obtained options to develop, or are holding land with a view to driving up values. However, this would also increase the tax liability of large housing developers who require several years' worth of development land in various stages of the development process. In England for example, the business models of larger housebuilders rely on such a pipeline due to the complexity and uncertainty involved in housing development (CW Economics, 2017). If the holding costs of several years' worth of development land were to increase, this could affect development viability, or more probably, increase the use of options over land purchase. Furthermore, any resultant decline in the land value of assets held by development companies could have implications for company balance sheets and consequent borrowing capacity. Whilst these problems could be alleviated or, potentially, solved through sensitive transition arrangements, they illustrate how a land value tax is a potentially blunt instrument for encouraging the development of under-utilised land, and brings with it potential economic risks.

\section{Valuation of the assets}

Once a tax base has been established, a further essential consideration is how to value each asset within that tax base. For LVT these assets are likely to be parcels of land and the difficulties associated with valuing unimproved land have perhaps dominated the academic and professional discourse on the implementation of LVT, not least the issue of separating land value from property entity value. The 
countries examined in this paper provide valuable insight into the practical issues that arise. These are described here, together with suggestions for addressing them.

Valuing unimproved land

An issue common to the countries reviewed for this paper is the necessity for good property records and valuations that are rigorous and defensible. However, as the case studies have illustrated, valuing unimproved land is difficult to do in a rigorous way because, with the exception of undeveloped land, land and improvements are not traded separately, thereby rendering comparable land transaction evidence scarce, particularly in built up areas; even ground rent evidence is not plentiful. Furthermore, it may not be possible to identify the original unimproved state of land where the land has been subject to improvements over many years, such that they have merged with the land (by levelling and planting for instance).

Separation of land value from property value is problematic, with many differing methods advocated but with no universally agreed solution (Hendriks, 2005; Boyd and Boyd, 2012, Milan et al., 2016). The normally preferred way would be to utilise comparable evidence of transactions of unimproved land, but this can be challenging due to lack of evidence. Alternatively, it is possible to conduct a residual valuation where the land value is derived by deducting the cost of improvements from the combined value of the land and improvements (RICS, 2008). However, this is often difficult to do accurately and may be too time consuming for taxation purposes. Other possible methods could be to apportion, in an accounting sense, the land from the overall value or to deduct the value of improvements from the value of the improved land, to arrive at an unimproved land value. Alternatively, it might be possible to index changes in unimproved land values within a certain area over time or to tax changes in property value, on the assumption that such changes will be primarily driven by shifts in underlying land value, rather than shifts in the value of the improvements.

However, even if these do present some potential solutions to this difficult technical valuation question, they suffer from a general lack of transparency and a risk that they not be understood by tax payers. A tax that is assessed by reference to the combined value of land and improvements is likely to have the benefit of more abundant market evidence with which tax payers are likely to be more familiar. Such problems could potentially challenge the integrity of a land value tax and expose the state to the risk of 
appeals, particularly in urban areas. The technical difficulty of how to value unimproved land, while not insurmountable, is considerable and prone to generating confusion and a lack of transparency. There needs to be a good understanding regarding what LVT is and what it is supposed to achieve and sufficient resource put behind the valuation exercise. Use of automated valuation models can reduce appeals against assessments, but currently these are only really practicable for domestic properties where reference to comparable capital transaction prices underpin values. However the Danish system which incorporates GIS (geographic information system) modelling with hedonic pricing techniques is considered by Milan et al. (2016) to offer the greatest potential moving forward. For the successful introduction of a land value tax, the issue of arriving at a credible land value method is a pre-requisite.

\section{Existing use or highest and best use}

The challenges associated with valuing land in its unimproved state are made potentially more complex if the valuation is to assume that the taxable asset (or land parcel) is assigned to its HABU rather than its existing use in cases where the two are different. Determining the value of land in its existing use would be a pragmatic solution, but this would not create any incentive to develop or sell land which is currently not developed to its potential. However, if land is to be valued based on its HABU then this brings with it technical issues associated with determining what actually is the HABU of the land parcel. Although these issues are not insurmountable, they can be difficult to address in a way that provides sufficient transparency or accountability. They are therefore open to challenge and appeal, which could undermine and discredit the tax.

The planning system is the mechanism by which the existing use of land is formally classified, and by which the HABU of land could be determined. This would be through existing land designations, as well as through changes to designations through plan making and the grant of new permissions for changes of use and more intensive use. There would need to be systems set up for valuers to be made aware of both the existing planning context and any possible changes to the planning consent for land being valued.

These difficulties may explain, at least partly, why event-based land value capture mechanisms are often preferred as a means of capturing betterment, especially in discretionary planning jurisdictions such as that in the UK. 


\section{$\underline{\text { Governance and administration }}$}

This paper has focused on the practical implementation issues associated with a land value tax. Perhaps the area where it is most difficult to separate these issues from political considerations is the allocation of responsibilities for a land value tax between state level and local level government. The case studies indicate that responsibilities are often separated: typically, establishment of tax base (state), valuation of taxable entities (state or local) and collection of tax revenue (local). This appears a rational approach; state government sets the LVT framework whereas often the revenue from a land value tax forms part of local-level expenditure. But it is also critical to make the purpose of the tax, its administration and the distribution of monies raised, transparent. Valuations can benefit from the economies of scale that centralisation offers.

A key practical consideration is the frequency of revaluations. For tax to be based on land or property values, regular revaluations are important, especially for urban land and property were values are higher, more variable and more volatile. Regular revaluations reduce the risk of the tax becoming discredited and reduce the risk of significant jumps in tax liability in developed areas with volatile land values; however, less frequent revaluations reduce administrative costs. Or perhaps there could be differential revaluations, with land in more developed areas revalued more frequently than land in more rural areas with more stable land values? In Denmark for example they operate a system whereby domestic properties are revalued one year and non-domestic the next. Frequent and regular revaluations both reduce the number of appeals and add to the credibility of the tax. For example, lack of revaluation is often cited in criticisms of the UK's council tax (levied on residential property), which in most areas has not seen revaluation for more than 25 years (Lyons, 2007; Hughes et al., 2018). Whilst an annual revaluation could be regarded as the ideal, a compromise of, say, five yearly revaluations with an indexation of values on an annual basis, taken from aggregated transaction data may be administratively easier, and still provide transparency and equity.

A land value tax requires a comprehensive and up-to-date land registry. This is needed to enable the correct identification of the extent of land ownership of the various plots of land being valued, the correct identification of the taxable entity and to avoid legal challenges. However, there can be difficulties in gathering, verifying and recording the necessary data in order to create the registry and this presents a significant practical impediment to the introduction of land value tax in many 
jurisdictions. Similarly, a land value tax requires up to date information regarding the land use (either existing use or $\mathrm{HABU}$ depending on the assessment regime) of each taxable land parcel. This is a substantial commitment and the existence of such a register in Denmark is one of the reasons why a land tax has been a longstanding feature in that country.

\section{Conclusion}

There is a strong theoretical case for LVT on the grounds that it provides a broad, stable and identifiable tax base that falls on the landowner and can provide a clear correlation with wealth; is not distortive of behaviour; is a just form of taxation of the 'unearned increment' in the value of land; and may promote the development of under-utilised land assuming the tax is levied based on its 'highest and best use' (HABU) rather than its existing use. Therefore LVT has a long history of advocates from Adam Smith and Henry George up to the present (Mirrlees et al., 2011; Wenzer, 1999). However, the arguments presented tend to concentrate on its compelling theoretical case, most do not consider the detail of how the tax might be implemented (a notable exception is Milan et al., 2016).

The review of LVT practice revealed that where a land value tax has been introduced, it generally exists alongside other forms of land and property taxation. Where LVT has been longstanding, it tends to be linked to a robust and precise register of land ownership which is closely aligned with the planning system, thereby making the assessment of the highest and best use of land more straightforward than it would otherwise be. Developments in Australia and New Zealand suggest that, as a country develops, pressure grows for assessments to be based on improved rather than unimproved land (McCluskey and Franzsen, 2005). The pressures seem to be practical rather than political, particularly the paucity of land sales data (especially in urban areas). In some jurisdictions, LVT has failed due to lack of transparency and public understanding associated with the difficulty of valuing unimproved land, and the lack of political will.

Consequently, the research for this paper identified a range of practical and political issues which would need to be considered before introducing a land value tax. These include: the need for a register of land ownership and forward planning of land use at plot level; the provision of a well-resourced and informed valuation profession; resources to undertake robust valuations which separate the value of land from the value of improvements for developed plots and do so on the basis of highest and best use; 
and the need for widespread political support for a new form of tax (which may be difficult to secure). These issues present significant uncertainty in comparison with already-existing forms of land and property taxation, such as local rates levied on the combined value of land and improvements. This might explain why politicians and policy-makers working in jurisdictions without LVT may be reluctant to switch from the existing land and property taxation regime.

We argue that it is for policy makers in and around governments to undertake detailed impact analysis and determine whether LVT is a good policy for the jurisdiction in question. In some cases, the technical and political issues may not present impediments sufficient to prevent the introduction of a land value tax. In others cases, it may be that LVT is considered off-limits politically and/or technically.

However, one thing is certain: for LVT to be successful it must be perceived to be legitimate by the tax payer and this means it must comply with the accepted principles of fair taxation. It would therefore be extremely important for any government seeking to introduce this tax to secure widespread political support, to clearly communicate the rationale for the tax to the electorate and to be able to robustly justify the intended tax rate(s) and resultant tax liabilities.

\section{References}

Almy, R. (2016) Effective and sustainable systems for valuing property for taxation: a comparison. Paper prepared for presentation at the 2016 World Bank conference on land and poverty. The World Bank Washington DC, March 14-18, 2016.

Anderson, J. E. (2009) A review of the evidence, Chapter 6 in Dye, R. F. and England, R. W. eds., (2009) Land value taxation: theory, evidence and practice. Lincoln Institute of Land Policy, Cambridge, Massachusetts.

Barrett, J. and Veal, J. (2012) Land Taxation: a New Zealand Perspective. eJournal of Tax Research, 10 (3) pp. 573-588.

Boadway, R. and Pestieau, P., (2018) The Dubious Case for Annual Wealth Taxation. ifo DICE Report, 16 (2), pp.3-7.

Boyd, T. and Boyd, S. (2012) Valuing the land component of improved investment property. Journal of Property Investment \& Finance, 30 (4), pp.338-353. 
Brown, P.K and Hepworth, M. A. (2002) A study of European Land tax Systems: a working paper. Lincoln Institute of Land Policy Cambridge, Massachusetts.

Bush, G. (2003) Local Government in Miller, R. ed. New Zealand Government and Politics. 3e. Oxford University Press, Oxford. Pp. 161-170.

C. W. Economics (2017) The role of land pipelines in the UK housebuilding process. Available from: https://cweconomics.co.uk/wp-content/uploads/2017/10/CWEconomicsReport Land Banking.pdf. (accessed 16 August 2019).

Commission on Local Tax Reform (2015) Just change: A new approach to local taxation. December 2015. Available from: http://localtaxcommission.scot/download-our-final-report/ (accessed 16 August 2019).

Connellan, O. (2004) Land Value Taxation in Britain: Experience and Opportunities, Lincoln Institute of Land Policy, Cambridge, Massachusetts.

Corlett, A., Dixon, A., Humphrey, D. and von Thun, M. (2018) Replacing business rates: taxing land, not investment: Introducing the Commercial Landowner Levy. Available from:

https://d3n8a8pro7vhmx.cloudfront.net/libdems/pages/43501/attachments/original/1535544506/10 39 Business Rates final.pdf (accessed 16 August 2019).

Dye, R. and England, R. (2010) Assessing the theory and practice of land value taxation. Lincoln Institute of Land Policy, Policy Focus Report, Code PF025. Lincoln Institute of Land Policy, Cambridge, Massachusetts.

Foldvary, F. and Minola, L. (2017) The taxation of land value as the means towards optimal urban development and the extirpation of excessive economic inequality. Land Use Policy, 69, pp.331-337.

Forster, G. A. (2000) Australia, Chapter 25 in Andelson, R.V. ed., (2000) Land-value taxation around the world: studies in economic reform and social justice. The American Journal of Economics and Sociology, 59 (5) pp. i-xlii+1-490.

Franzsen, R.C.D. (2009) International experience, Chapter 3 in Dye, R. F. and England, R. W. eds., (2009) Land value taxation: theory, evidence and practice. Lincoln Institute of Land Policy, Cambridge, Massachusetts.

Franzsen, R. and McCluskey, W. (2000) Some Policy Issues Regarding the Local Government: Property Rates Bill. South African Mercantile Law Journal, 12 (1), pp. 209-223.

Franzsen, R. and McCluskey, W. eds., (2017) Property tax in Africa: Status, challenges, and prospects. Lincoln Institute of Land Policy, Cambridge, Massachusetts.

George, H. (1879) Progress and Poverty, Robert Schalkenbach Foundation, New York. 
George, H., (1881) The Land Question. JC Durant, reprinted 2011.

Gupta, R. (2016) Filling the land tax void. Auckland University of Technology, New Zealand.

Hendriks, D. (2005) Apportionment in property valuation: should we separate the inseparable? Journal of Property Investment \& Finance, 23 (5), pp.455-470.

Hughes, C., McCluskey, W., Sayce, S., Shepherd, E. and Wyatt, P. (2018) Investigation of potential land value tax policy-options for Scotland. Final report for the Scottish Land Commission. Available from: https://landcommission.gov.scot/wp-content/uploads/2018/12/Land-Value-Tax-Policy-Options-forScotland-Final-Report-23-7-18.pdf (accessed 16 August 2019).

Intergenerational Commission (2018) A New Generational Contract. The Final Report of the Intergenerational Commission for the Resolution Foundation. Available from: https://www.resolutionfoundation.org/advanced/a-new-generational-contract// (accessed 16 August 2019).

IPPR (2005) Time for land value tax? Institute for Public Policy Research and the Department of Politics and International Relations at the University of Oxford. Available from:

https://www.ippr.org/files/images/media/files/publication/2011/05/Land Value Tax full 1380.pdf (accessed 16 August 2019).

Lefmann, O. and Larsen, K. K. (2000) Denmark, Chapter 10 in Andelson, R.V. ed., (2000). Land-value taxation around the world: studies in economic reform and social justice. The American Journal of Economics and Sociology, 59 (5) pp. i-xlii+1-490.

Lindegaard, L. (2018) exchange of emails with the authors May 2018.

Lyons, M. (2005) Lyons Inquiry into Local Government Consultation Paper \& Interim Report, December 2005.

Lyons, M. (2007) Place shaping: a shared ambition for the future of local government. Lyons Inquiry into Local Government. Final report. March 2007.

Malme J. and Tiits, T. (2001) The Land Tax in Estonia, Chapter 3 in Malme, J.H and Youngman, J. M. eds., (2001) The development of property taxation in economies in transition. World Bank Institute, Washington D.C.

Mangioni, V. (2016). Land tax in Australia: Fiscal reform of sub-national government. Routledge, New York.

McCluskey, W.J. (2005) Site value taxation in Queensland, Chapter 8 in W.J. McCluskey and R.C.D. Franzsen, eds., (2005) Land value taxation: An applied analysis. Routledge, London and New York. 
McCluskey, W. and Franzsen, R. (2004) The basis of the property tax: A case study analysis of New Zealand and South Africa. Lincoln Institute of Land Policy Working Paper WP04WM1. Lincoln Institute of Land Policy, Cambridge, Massachusetts.

McCluskey, W. and Franzsen, R. (2005) Land value taxation: An applied analysis. Routledge, London and New York.

Milan, B., Kapfer, D. and Creutzig, F. (2016) A systematic framework of location value taxes reveals dismal policy design in most European countries. Land Use Policy, 51, pp.335-349.

Mirrlees, J., Adam, S., Besley, T., Blundell, R., Bond, S., Chote, R., Gammie, M., Johnson, P., Myles, G. and Poterba, J. (2011) Tax by design: the final report of the Mirrlees review. Institute for Fiscal Studies. Available from: https://www.ifs.org.uk/publications/5353 (accessed 16 August 2019).

Muller, A. (2005) an updated version of Muller, A (2000) Property Taxes and valuation on Denmark paper to an OECD Seminar on Property Tax Reforms and Valuation Vienna 19-21 September 2000.

RICS (2008) Valuation of Development Land. 1e. Valuation Information Paper. Royal Institution of Chartered Surveyors.

Smith, Adam (1776). An Inquiry in to the Nature and Causes of the Wealth of Nations, Book V, Chapter 2, Article I: Taxes upon the Rent of Houses. Edited by S.M. Soares (2007). MetaLibri Digital Library. Available from: https://www.ibiblio.org/ml/libri/s/SmithA WealthNations p.pdf (accessed 19 August 2019)

Smith, S. (2005). Land tax: an update. Briefing paper 5/05. New South Wales Parliamentary Library Research Service.

United Nations (2011) Land and property tax: a policy guide. UN Habitat and the Global Land Tool Network.

Vickers, A. (2009) Visualising Landvaluescape PhD Thesis, Chapter 6: Selected Overseas Comparisons pp. $207-249$

Wenzer, K.C., (1999) Land-Value Taxation: The Equitable Source of Public Finance. Routledge, New York. Youngman, J.M. (2016) A Good Tax: Legal and Policy Issues for the Property Tax in the United States. Lincoln Institute of Land Policy, Cambridge, Massachusetts. 